P-353

ダンベル型神経原性腫瘍の胸腔鏡下手術中 に発生した偶発症一䯣液流出：神経根引き 拔きによる硬膜損傷一

\title{
大阪警察病院 外科
}

高松 純平, 城闹哲夫, 圾卷 靖, 竹内 麦穂, 樋口貴宏

ダンベル型神経原性腫瘍の胸腔鏡下手術中に神経根引き抜 きによる硬膜損傷のため髄液流出を認めた 1 例を経験した ので考察を加えて報告する。【症例】55筬，女性。Von Recklinghausen 氏病で当院神経外科通院加療中，後縦隔 に異裳㓌影を指摘され当科紹介受診となった。CT，MRI でTh1-2におよぶダンベル型神経原性腫湯と診断。神経外 科で椎马切除術 (Th1-2) 施衍後, 胸腔鏡補助下後縦隔腫 瘍摘出術を施行した，胸腔鏡下手術中，腫瘍摘出の際，完 全に切除されていなかった神経根の一部引き拔きによる硬 膜損傷を来たした。モニターで髄液の流出を確認できたた め, 閉胸後神経外科で損傷された硬膜を修復し手術を終了 した。術後経過良好で第29病日退院.【考察およびまとめ】 硬膜損傷が発生した背景は1。内視鏡下手術に移る際，椎 戸切除侍の神経根の完全切断の確認がされていなかった。 2.内視鏡下手術中に腫濠に過剩な率引がかかった。本症 を回避するためには，1。神経外科医との絊部にわたる乎 術内容の確認. 2. 本内視鏡下手術に際して，腫韵と神経 根の位置関係を常に把握し, 過剩な吽引をさけるための腫 痬への爱護的操作．以上が必装である。

P-355

国立䂟国病院呼吸器外科

\section{具壁 翰夫, 王木 孝颜, 河本 伸洋}

胸骨全切除術を要する巨大な胸姐腫瘍の手術では，胸壁の 再建が問題となる。再建にチタンメッシュを用いて艮好な 経過となった孤立性形質細胞腫の1例を経験した。宊例は 52 藏男性で，主挀は前胸部腫瘤であった。3年前より前胸 部皮下に腫瘤を自覚し, さらに1年前より左側䅡部にも腫 瘤を認めていた。急激な腫瘤の増大と，自発痛を認めたた めに当院を受診した．視診触診で前胸部正中に17 $\times 11 \mathrm{~cm}$ の巨大な腫瘤を皮䖉直下に認め，左側䅡部にもリンパ節転 移を疑う $7 \times 6 \mathrm{~cm}$ の腫刻を諗めた。CTで胸骨を融解し周 囲に压排性に增大する，径 $13 \mathrm{~cm} の$ 腫澺を諗めた。骨シン チなどの全身㭘索では頚部腫瘍以外の転移紧は認めなかっ た。生検により形質細胞腫と診断した。2期的に切除術を 施行した。まず，胸骨腫瘍を切除し胸膜，心膜の修復に marlex meshを用い，全切除した胸骨の再建に0.6mm 厚 のチタンメッシュを使用した。その上を大胸筋皮弁で鳆っ た. 3 ケ月後に左側頝部の腫瘍を切除した。術後経過は良 好であったが, 胸腔内再発を認める。術後 3 年経過し治療 中である、胸骨全切除後のチタンメッシュによる再建は術 直後より十分な胸壁の強度を期待でき，有用な方法と考え られる。
P-354

胸腔鏡補助下および後方アプローチにて切 除したDumbbell 型神経鞘腄の 2 例

|藤枝市立総合病院心臟呼吸器外科, “榛原総合病院呼 吸器外科, 焼津市立総合病院外科, 磐田市立総合病院 呼吸器外科, "すずむらクリニック

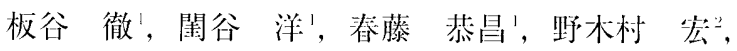
北 雄介 ${ }^{2}$, 小林 亮 ${ }^{3}$, 大井 諭 ${ }^{4}$, 杉村 久雄 ${ }^{5}$

後粉隔原発神経鞘腫のうち椎間孔を通り脊柱管内に達する Dumbbell型神経鞘腫は比較的稀である。今回我々は胸腔 鏡と後方アプローチの併用で切除し得た 2 例を経験したの で報告する。【症例 1】34歳, 女性。無症状。検㟝で胸部 異常影を指摘された。胸部X線写真で第 10 胸椎左緣に半 球状の腫瘤影あり，CT, MRIにてDumbbell型神経鞘腫 が疑われた，胸脭鏡下に腫瘍の外側の剥離を行い，椎間孔 入行部で一旦腫湯を切断。背部正中切開にて片侧椎弓切除 を施行し，暊微鏡下に腫癔を硬膜より剥離，摘出した。 【症例2】74歳, 女性。無将状。検診で胸部異常影を指摘 された．胸部X線写真で第 $11 ， 12$ 胸椎存緣に腫瘤影あり， CT，MRIにて Dumbbell 型神経鞘腫が疑われた。脊柱管 内の腫淘の大きさが比較的小さかったため，まず胸腔鏡下

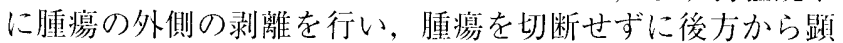
微鏡下に腫挰を硬膜から剥離し, 胸腔より据出した。【結 語】本術式は胸腔鏡, 顕微鏡を朋い, 比較的低侵襲で客全 な術式であると考えられた。また形状によっては牌疷を切 断せずに摘出することが可能であった。
P-356

綾部脯立病院 外科
【症例】71歳，男性。H11年頃より前胸部に腫瘤が出現し， 近医でfollow up されていた，腫瘤が增大傾向の為，精查 加療目的に当院紹介となった。腳骨腫瘍を認め，経艾的針 生検の結果adenocarcinomaの診断を得た。転移性腫湯を 考え，全身検索を行ったところ，PSA高值及び前立腺生 検にて前立腺癌の骖断を得た。その他，全身に買常听見は 認めなかった。【手術】胸骨柄部のみを残す形で胸骨体部 全摘（而側第 $2 \sim 7$ 肋軟骨合併切除，一部胸壁全層切除） を行った。骨性胸郭欠損部の再建にはMarlex meshの4枚 重ねを使用し，左在の胁骨や胸骨柄に緊張を持たせ強く固 定した。皮膚軟部組織に関してはskin flapを作製し直接 縫合閉鎖した。【結果】術後は軽度無気肺を認めたが，そ の他呼吸不全，胸壁動摇，感染症などの合併症を認めず， また創部の治癒も問題なく，順調に経過した。現在，原発 巣である前立腺癌に対し化学療法中である。【結浯】前立 腺原発と思われる孤立性転移性胸骨腫瘍に対して胸骨体部 全切除とMarlex meshによる胸壁再建術を行い良好な結 果を得た1例を経験したので報告する。 